\title{
THE LUTHERAN LITURGY: THEOLOGICAL PRINCIPLES, STRUCTURE, AND HISTORICAL DEVELOPMENT
}

\author{
Darius Petkūnas \\ University of Klaipèda, University of Helsinki
}

\begin{abstract}
The article examines the Lutheran liturgy in a theological and historical context. It analyzes its structure, surveys the criteria for liturgical reforms in the sixteenth century, considers the possible classification of a wide variety of Lutheran agendas as well as the influence of pietism and the Enlightenment on the liturgical life of the church. Particular attention is given to the Prussian Union and its agenda which has awakened a new liturgical sensibility among the Lutheran Churches and prompted them to re-appreciate their confessional and liturgical heritage, leading to the preparation of new agendas that more clearly reflected their confessional identity. The influence of liturgical movements on the sacramental life of the church and the results of the liturgical reforms carried out by the Lutheran churches of the United States, Germany, and Scandinavia in the twentieth century are also considered. KEY WORDS: Liturgy, Lutheran Church, Mass, agenda, church order.
\end{abstract}

\section{Anotacija}

Straipsnyje aptariami Liuteronu Bažnyčios liturginès teologijos aspektai, jos struktūra ir istorinè raida. Apžvelgiami liturginès reformos kriterijai XVI a., pateikiama agendu (mišiolu ir apeigynu) klasifikacija pagal jų turinio kriterijus, analizuojamas pietizmo judejimo, Apšvietos epochos ir Prūsijos tarpbažnytinès Unijos poveikis bažnyčios liturginiam gyvenimui. Unija paskatino liuteronu bažnyčias iš naujo ịvertinti ju konfesini bei liturgini paveldą ir parengti naujas agendas, aiškiai liudijančias bažnyčios konfesinę tapatybę. Straipsnyje vertinamas XX a. liturginiu judejimu poveikis bažnyčios gyvenimui, aptariami JAV, Vokietijos ir Skandinavijos liuteronu bažnyčiu liturginiu reformu rezultatai.

PAGRINDINIAI ŽODŽIAI: liturgija, Liuteronu Bažnyčia, Mišios, agenda, apeigynas.

DOI: http://dx.doi.org/10.15181/mtd.v0i7.2308

When one surveys Lutheran liturgy in Germany, Eastern Europe, and Scandinavia, one is immediately struck by the wide variety of agendas and church orders. In his Bibliotheca Agendorum of 1726, Hermann Caspar Kö- 
nig counted 351 such documents published up to this time in the Holy Roman Empire. ${ }^{1}$ By adding to this list additional orders and agendas that had not yet been identified and those prepared outside the Holy Roman Empire, the total number of pre-Enlightenment liturgical sources would certainly exceed $400 .^{2}$ Considering such a large variety of Lutheran liturgies, one may ask what made all of them Lutheran and what should be regarded the irreducible foundation of the Lutheran liturgy?

The study of the Lutheran liturgy is further intricate due to the appearance of inventive Enlightenment liturgies. At least 50 official and unofficial

Hermann Caspar König supplemented with additional data a large collection of church ordinances that had been identified in the early eighteenth century by Superintendent Christian Julius Bockelmann. This number still was incomplete due to the complexity of the territories of the Holy Roman Empire which made it difficult for both scholars to examine all sources. Furthermore, the Scandinavian agendas and church orders were outside the scope of their study. It should also be noted that Bokelmann's collection added some nonProtestant sources and documents, such as hymn books and pamphlets, which did not belong to the church orders or agendas (Bibliotheca Agendorum, 1726, p. $1 \mathrm{ff})$. Aemilius Ludwig Richter in Die evangelischen Kirchenordnungen des XVI. Jahrhunderts of 1846 presented a list of 165 agendas and church orders published in the sixteenth century along with liturgical fragments of some of them. A full description of the sixteenth-century Lutheran and Reformed orders in the former German Empire is given by Emil Sehling in his five volume study, Die evangelischen Kirchenordnungen des XVI. Jahrhunderts, 1902-1913. Ten more volumes appeared in 1955-80 when the project was resumed under the auspices of the Evangelical Church of Germany (Evangelische Kirche in Deutschland (EKD)) and the German Research Foundation (Deutsche Forschungsgemeinschaft (DFG)), and six more volumes were published when it was undertaken in 2002 by the Heidelberg Academy of Sciences (Heidelberger Akademie der Wissenschaften). At the time of its completion, the collection will comprise 24 primary volumes, some of which will be divided into sub-volumes.

2 Joseph Herl identified 400 pre-Enlightenment Lutheran liturgies compiled in the Holy Roman Empire. He classified them according to whether the document was prescriptive (273 sources) or descriptive (127 sources) or whether it was a printed source (129 sources) or a manuscript (271 sources) (Herl, 2004, p. 282). 
neological agendas had been printed in this period which attempted to provide liturgical forms acceptable to men of the "age of reason" (Graff, 1994, p. 4-26). Worship was adjusted to agree to modern view of God, man, and the world and was accommodated to the speech, song, and the spirit of the new age. The study of the nature of the Lutheran liturgy becomes even more complex by the appearance in 1821-24 of the Prussian Union agenda of King Friedrich Wilhelm III who believed that he could successfully create a single liturgy for the Reformed and Lutheran Churches which would not contradict the theological position of either church. Doctrine and liturgy in his opinion were not closely related and could be successfully separated by providing a work which each of these two groups could look at and undertake from its own point of view. Many Lutherans would eventually state that the use of the new liturgy violated their confession. This was followed by the awakening of a new appreciation of the church's Confessions and liturgical treasures.

A wide variety of liturgies indicates that Lutheran unity is not a unity created by the forms of worship, but rather the faith that Lutherans confess and express in their liturgies is unifying. The liturgy is not a mark of the church or her unity. Although the expressed forms of liturgy may be many and varied, the faith is and remains the same.

The present study examines the Lutheran liturgy in its theological and historical context. It gives particular attention to the theological principles of the liturgy and the structure of the Lutheran Mass. The essay recounts the main historical developments and provides a possible classification of liturgies according to their types and criteria. Criticism of external worship by pietists and liturgical innovations during the age of Enlightenment are also examined. Moving beyond the Prussian Union agenda, the study describes the awakening of a new liturgical sensibility and a heightened awareness of the need for liturgical restoration, leading to the publication of new agendas in the nineteenth and twentieth centuries, based on a renewed appreciation of the church's liturgical treasures. ${ }^{3}$

3 For more details on what is central and secondary in the Lutheran liturgy, see the author's article: Petkūnas D. (2013). Center and Periphery in the Lutheran Liturgy. Confessional Identity and Ecumenical Perspective. Propter Christum: Christ at the Center. Saint Louis: Luther Academy, p. 243-256. 


\section{Theological principles of the Lutheran Liturgy}

The Lutheran liturgy, also referred to as the Mass or Holy Liturgy, is the divine service which includes in it the preaching of God's Word, both his Law and his Gospel, and Holy Communion in which the communicants receive both the body and blood of Christ in the consecrated elements. It includes also the sacrificial worship of prayer, praise, and the thanksgiving of God's people. Considered more broadly, liturgy may be taken to include also the daily offices of Matins and Vespers, Holy Baptism, Confirmation, Marriage, Confession and Absolution, the Communion of the Sick, the Commendation of the Dying, the Burial of the Dead, and other rites and services.

The Mass, which is most often called the Divine Service, in Lutheran Churches is to be thought of chiefly as the work of God who gathers his people to bless and refresh them with his life-giving Word and the body and blood of Christ in the Sacrament. It is by God's doing that his congregation is enabled to offer him Eucharistic praise and thanksgiving. The officiating clergyman, usually called the pastor, minister, liturgist, or officiant, stands in the place of Christ who is described in the New Testament as the High Priest and Liturgist of his people.

The Apology of the Augsburg Confession makes a distinction between the sacramental and sacrificial elements of the service (The Book of Concord, 2000, p. 270-272 [AP, Art. XXIV]). The clergyman speaks Christ's sacramental Words absolving, blessing, and nourishing his people and administering to them the Holy Sacrament by which faith is strengthened, forgiveness is made new, sinners are reconciled and made one with Christ and are given a foretaste of the heavenly banquet. These are sacramental acts - acts of God by which, through means, he offers and bestows his wholesome grace and blessing. Included also among these is the preaching, which Lutherans understand to reach its high point in the proclamation of the Gospel. It communicates the saving work of Christ in human words. The sermon also imparts practical instruction. Included also among sacramental acts are the Salutation, the Eucharistic preface ("Lift up your hearts, etc"), the Blessing, usually the Aaronic Benediction, which concludes the rite. 
The liturgy also includes elements of a sacrificial nature. These are acts of worship directed toward God - words and acts of the church in faithful response to the gracious words and acts of God. They are priestly acts of praise, prayer, and thanksgiving performed by the baptized people of God whom he has made to be his priestly people (Exodus 19, Romans 12, 1 Peter 2, Hebrews 13). Included among these acts are the prayers of the people, the confession of sins, the collect particular to the day, the prayer of the church and all other prayers, the church's confession of faith (creed), hymns and songs, including also the verses of psalms used in the introit, gradual, and offertory.

The shape of the Lutheran divine service is the traditional Mass of the Western Church. The two part structure of Missa Catechumenorum and Missa Fidelium is retained, along with traditional liturgical forms, readings, prayers, vestments, chants, et al. Private Masses, Masses for the repose of the dead or for the fulfillment of particular intentions are not celebrated in the Lutheran Church. Only a common public Mass is to be celebrated in the church, usually on Sundays and other church festivals. Eliminated is any notion that the celebration of the Mass is a propitiatory sacrifice, offered by the church to God, and which confers grace simply by virtue of the fact that it is performed. From the time of the Reformation, Lutherans stated this to be a central point at issue between them and their opponents. According to Lutheran doctrine, the Mass does not confer merit ex opere operato on either the living or the dead, nor does it offer the remission of sins, of guilt, or of punishment simply by virtue of its being offered. Those who receive its benefits are those who hear and hold fast to the Word proclaimed and the blessings given and who receive the body and blood of Christ in the Sacrament. As noted, the point at issue is the notion of sacrifice.

In the churches where the altar stands against a wall or backed by a reredos, it is the custom that in the sacramental acts the liturgist faces the people. In the sacrificial acts, when he speaks with or on behalf of the people, he faces the altar.

The nature of the sacrificial acts is to be clearly understood so that it is not thought that God is propitiated or reconciled by means of them. Consequently, it is necessary to distinguish between the propitiatory sacrifice (sacri- 
ficium propitiatorium) - the sacrifice which atones for and reconciles sinners to God and the Eucharistic sacrifice (sacrificium eucharistikon), the sacrifice of praise and thanksgiving offered to God in grateful thanksgiving for his saving work.

Properly speaking, there is only one propitiatory or atoning sacrifice, the self-offering of Christ Jesus. The Levitical sacrifices described in the Old Testament pointed forward to it and obtained for those who offered them legal righteousness that restored them to the community. These Levitical sacrifices came to an end with the sacrifice of Christ. Accordingly, the Mass is not to be considered a continuation of the Levitical sacrifices, nor is the New Testament priesthood a continuation of the Levitical priesthood.

The sacrifice of thanksgiving also includes prayer, praise, thanksgiving, the preaching of the Gospel, the confession of faith and the confession of sins, and all the good works of God's people. Such sacrifices do not reconcile one to God. They are offered in thanksgiving by those who have been reconciled to God by his gracious work. If the Mass is to be called a sacrifice, this may be allowed for the sake of the Eucharistic offering of prayers, praise, thanksgiving, and other worship found in it. However, it is to be made clear that the Mass is not a propitiatory sacrifice. It is a Eucharist in which the faithful, receiving the fruit of Christ's propitiatory activity, thankfully respond in their own priestly Eucharistic activity. This activity is by no means limited to the divine service. It manifests itself in a faith active in love. The church's diaconal activity is just such an expression of Eucharistic thanksgiving, always moving outward from the proclamation of the Gospel and the administration of God's gracious gifts from font and altar.

The axiom lex orandi, lex credendi ("the rule of prayer [is] the rule of belief") in the Lutheran Church is understood that the liturgy is the way the church confesses its faith. The liturgy bears public witness to the faith of the church, it is an expression of faith, however, not faith's source and norm. The church's lex orandi flows out of the lex credendi. In the liturgy, the church puts into words and actions the faith which it otherwise articulates in its creeds and confessions. 


\section{The Structure of the Lutheran Mass}

The classical Lutheran Mass is essentially the Western Mass with the removal of those elements which obscure the uniqueness of the propitiatory sacrifice offered by Christ. Lutherans insist that the central purpose of the Mass is the Communion of the sacred body and blood of the Lord, who was born of Mary and hanged on the cross, by which man's redemption is accomplished. Lutherans found the Western Mass to be a proper vehicle for the divine service, so long as it was shorn of any notion that the Mass itself is an atoning sacrifice offered by the church or the church's offering of Christ to the Father in an unbloody manner. Thus prayers and actions in the Missa fidelium which supported this notion were eliminated.

The traditional Missa Catechumenorum, usually called the Service of the Word, is little different from that found in the pre-Reformation orders. It continues to use a traditional form of that Mass - the ordinarium (invariable texts) and its propria (variable parts). Included among the propria are the introit, salutation and collect, epistle, gradual and alleluia or tract, or sequences, and gospel. In some cases, the introit and gradual are replaced by appropriate liturgical hymns. In most places, the Apostolic or Nicene Symbols are recited between the Gospel and the Sermon, although since the reform of the Roman Mass in the twentieth century it is now common to recite the creed after the sermon. Often Luther's creedal hymn, "We All Believe in One True God" ("Wir glauben all' an einen Gott"), is used. In many liturgies, a preparatory office of public confession and absolution precedes the service itself.

Differences between Lutheran divine service and the medieval Mass are most evident in the Missa Fidelium, the Service of the Sacrament, for all notions of the Mass itself as a propitiatory sacrifice offered by the church have been eliminated. These notions predominated in the old Offertory and the Canon of Mass, in which the Our Father and the Words of Christ over the bread and wine were imbedded. In Lutheran orders, the sermon is followed by the Offertory in which the people offer their gifts for the use of the church, and bread and wine for the Lord's Supper are prepared. The prayer of the church includes thanksgiving, supplications, and intercessions. Then come the Eucharistic preface, the Sanctus, the Verba and Our Father, the Pax Domini 
(often called the "little absolution"), the Agnus Dei, the Communion, versicle and Post-Communion collect, and the Aaronic Benediction. Many Lutheran orders also include a more fully developed Eucharistic Prayer after the Sanctus and before the Verba. The body and blood of Christ are consecrated for the purpose of the Communion of the people, and ordinarily, all consecrated elements are to be consumed during the Communion, excepting where some are set aside for the communion of the infirm.

The rich use of hymns of praise and prayer which are confessional in nature play an important role in the Lutheran Mass. This is exemplified in the earliest Lutheran hymns, Luther's "Dear Christians, One and All Rejoice" ("Nun freut euch, liebe Christen g'mein"), 1523, and "Salvation unto Us Has Come" ("Es ist das Heil uns kommen her") by Paul Speratus 1523. Unique to Lutheran liturgies since the days of Luther is the directive that Words of Christ over the elements (Verba Christi) ought to be sung in the Gospel tone. The Lutheran Churches continued the practice of chanting introits, collects, epistles, graduals, gospels, antiphons, and responsories.

In the Lutheran Church, great prominence is given to the sermon, for it is understood that faith comes by hearing the Word. The purpose of the sermon is not merely to convey information and instruction, but by means of it God the Holy Spirit sacramentally conveys the saving work of Christ to those who faithfully receive these words. This places a heavy responsibility on the preacher to convey clearly and boldly what the word says without adding to it or taking from it in such a way as to change it.

The Mass is ceremonial in nature and includes a prescribed series of readings, prayers, vestments, altars, lighted candles, and other ceremonial elements. Included also among ceremonies are kneeling for prayer, the sign of the cross, the bowing of the head, and other bodily actions. Church decorations, pictures, and statues are also included among ceremonies. It was to be understood, however, that no ceremony in and of itself merits grace and mercy from God. Ceremonies were retained because they seemed to be useful in teaching and as aids to prayer. They were of value in so far as they taught and directed the people to live a life of faith and good works. 
Since the Reformation, most services have been in vernacular languages, although the use of the Latin language in prayers and hymns was retained where appropriate and useful to do so. Preaching, however, was always to be in a language understood by the people. Before the altar, the officiants and other ministers often continued to wear the alb and chasuble and in many cases also the cincture, stole, and in some cases, the maniple. The cope is also worn on appropriate occasions. The cassock or "talar" was originally street dress, and in many places, preachers removed their vestments before the sermon and preached wearing the "talar". Only in the nineteenth century did Prussian civil authorities require by law that Lutheran pastors wear the "talar" and preaching tabs ("beffchen") both in the pulpit and before the altar. This led many of them to abandon their traditional albs and surplices. In recent times, many Lutheran Churches have returned to the older vestment tradition of albs, surplices, and chasubles (Piepkorn, 1956, p. 12 ff.).

The Lutherans have continued to celebrate the church's year of grace according to the calendar tradition of the Western Church, including the seasons of Advent, Christmas-Epiphany, pre-Lent, Lent, Easter, Ascension, Pentecost, and Trinity and the lengthy season following. Most of the medieval saints' days were eliminated from the calendar, although the days commemorating the apostles and evangelists, and St. Mary the Virgin, and All Saints Day were continued in most places. The amber days were observed as days of special prayer. Added were days commemorating the presentation of the Augsburg Confession (June 25), the Lutheran Reformation (October 31), the festival of the Harvest (Sunday after the feast of St. Michael and All Angels), and other special observances. In the last several decades, many Lutheran Churches have adopted the calendar reforms specified in the Ordo Lectionem Missae, according to which the Sundays after Epiphany and Pentecost are now designated ordinary Sundays, and a three-year calendar of readings replaces the traditional pericopes.

\section{Historical Review of the Lutheran Mass}

The Lutheran form and use of the Mass derive from theological principles articulated by Martin Luther. In the period 1517-1523, Luther did not 
direct primary attention to the structure and reform of the Mass but to the Sacrament of the Altar itself and the fruits of Communion. In his 1519 Eyn Sermon von dem Hochwirdigen Sacrament, des heyligen waren Leychnams Christ (The Blessed Sacrament of the Holy and True Body of Christ, and the Brotherhoods), he centered his attention on the significance of the body of Christ in the lives of Christians and advocates Communion of both the consecrated bread and the cup by the people (LW 35, 1960, p. 45 ff.). In Eyn Sermon von dem newen Testament, das ist von der heylige Messe (A Treatise On The New Testament, That Is, The Holy Mass), 1520, he spoke out against the medieval doctrine of the Mass as an unbloody repetition of Christ's sacrifice. He rejected the notion that the Mass is a propitiatory sacrifice and good work and insisted that Masses for the dead are a deviation from the purpose of the Mass. The Words of Christ's Testament, his Words of Institution, stand at the center of the Mass and should be said aloud for all to hear. He again complained against the withholding of the cup from the laity (LW 35, 1960, p. 75 ff.). Later that year, he published De Captivitate Babylonica Ecclesiae (The Babylonian Captivity of the Church) in which he criticized some medieval notions and practices, such as the withholding of the cup from the laity, the mandatory agreement to the doctrine of transubstantiation, and the notion that the Mass was regarded to be a sacrifice for $\sin$ (LW 36, 1959, p. 3 ff.). He continued his argument in Vom Missbrauch der Messen (The Misuse of the Mass), 1521, stating that the notion of sacrifice must be removed from the Mass along with the notion that it is a good work that reconciles one with God. He also argued for the abolition of private Masses where no communicants were present. Nowhere did Luther argue that the Mass itself should be abolished or that its form should be radically changed. Purified from irregularities, the Mass was seen to be a suitable form of worship that extols Christ. Medieval additions which turned the Mass into a work of man were to be removed. The Mass should not be a work of man by which the church seeks to placate the Father by offering him his Son in an unbloody manner. It is a proclamation of the Gospel and a gift of communion with Christ (LW 36, 1959, p. 127 ff.). 
In the writings of this period, Luther made no attempt to do more than articulate general principles for the reform of the Mass. He did not dictate specific changes to priests and congregations. They would still use their missals with the understanding that what mitigated against the Gospel should be eliminated. It was understood that the Words of Christ over the bread and cup should be said aloud and heard by all. Indeed they should repeat them in their hearts as the priest said them at the altar, and the people should receive both the body and the blood. No directions were given about the language of the service.

In the absence of clear directions, some clergy produced alternatives to the Mass. In Wittenberg, Andreas Karlstadt, who lacked Luther's insights and appreciation, in 1521 replaced the Mass with a service he himself constructed de novo. To counteract this, Luther preached eight sermons in Lent 1522 in which he stated that pastors should omit those parts of the Mass which made the sacrament a propitiatory sacrifice, but they should continue to use the Mass itself. In answer to a plea from the congregation at Leisnig in Saxony early in 1523, he wrote a short letter, entitled Concerning the Order of Public Worship (Von ordenung gottis diensts ynn der gemeyne). In it, he stated that while order must be restored and all things must be done so that the Word of God may have a free course, one should not make hard and fast rules. He said that Mass ought not to be celebrated during the week, excepting if there were communicants. On Sunday, there should be a common Mass at which the pastor selects readings and chants. Suitable responsories and antiphons should be retained. Daily offices should be prayed in the church every morning and evening, and the Masses should be held on Sunday with the usual chants. He suggested that many of the festivals of the saints should be discontinued and that some be celebrated or perhaps transferred to the nearest Sunday (LW 53, 1965, p. 7 ff.).

At the urging of Nicholas Hausmann of Zwickau and others, Luther decided to publish a report of the manner in which the Mass was celebrated and Communion was offered at Wittenberg. His Formula missae et communionis pro ecclesia Vuittembergensi (An Order of Mass and Communion for the Church at Wittenberg), written in Latin, was not meant to be a prescriptive 
order of the Mass but a guide with directives which would be helpful to those responsible for ordering public worship in the congregations. The structure of the medieval Mass and its language were retained. It followed the traditional pattern: Introit (may be replaced in time with a whole psalm) - Kyrie eleison - Gloria in excelsis - Collect - Epistle - Gradual and alleluia (sequences at Christmas and Pentecost) - Gospel - Nicene Creed - Sermon in the vernacular (may be put before the introit) - Preparation of the bread and wine - Preface (Dominus vobíscum, Sursum corda, Gratias agamus, Vere dignum et justum est) - the Words of Institution (Qui pridie and Verba testamenti) - Sanctus and Benedictus qui venit - Elevation - Lord's Prayer - Pax Domini - Agnus Dei and Communion Prayers - Communion (distribution formula: "The body (the blood) of Christ preserve your soul to life eternal") Salutation - Post-Communion collect - Benedicamus Domino - Benediction (Number 6: 24f. or Psalm 67: 6f.). Luther suggested that the bishop should decide whether all should receive the body of Christ after the blessing of the bread and then receive the blood of Christ after the blessing of the cup, or whether both elements should be blessed before distribution. However, he recognized that to separate the giving of the body and the blood would be an innovation requiring changes in the prayers (LW 53, 1965, p. $15 \mathrm{ff}$.).

Here for the first time, Luther provided specific suggestions concerning the use of the Mass. He implemented the principles he had stated earlier and clearly distinguished between what is essential and what is not. Vestments, candles, incense, etc., might be retained, but the Offertory and the Canon must be eliminated.

The Formula missae was used as the basis for the divine service in Wittenberg and elsewhere in Latin and in German translation. It provided source material for Andreas Döber in his 1525 Nürnberg German Mass and was used as the basis for the first Ducal Prussian church order, Artickel der ceremonien vnd anderer Kirchen Ordnung (Article of Ceremonies and Other Church Order) of 1525 (Artickel der ceremonien, 1526, p. 1 ff.), and subsequently the Kurtz Ordnung des Kirchendiensts (A Short Order of the Church Service) of Riga 1530 (Kurtz Ordnung, 1530, p. 1 ff.). 
Luther's own love for Latin as a liturgical language made him reluctant to prepare an order entirely in German. However, others were writing German services. In addition to the liturgies of Nürnberg and Prussia, Theobald Schwartz introduced a German service in Straßburg in 1524, and a complete German service was held in Schwäbisch-Hall by Johannes Brenz in 1525 (Smend, 1896, p. 8). In general, it can be said that these services were influenced to a greater or lesser degree by Luther's Formula missae.

It was not until 1526 that Luther bowed to the necessity of providing a Mass entirely in the German language, Deutsche Messe und Ordnung des Gottesdiensts (The German Mass and Order of Divine Service). It was meant for the benefit of those who did not know or use Latin. He was dissatisfied with the German services that have been produced. They did not use German well. They offered wooden translations or breathed an overly sentimental spirit, as was the case in Thomas Müntzer's 1524 Mass at Allstedt (Pahl, 1983, p. 9). The 1524 Straßburg Mass gave too much attention to the instruction and gave little attention to the church year and traditional pericopes. Luther wanted a service that would maintain a sense of continuity with the past and retain the spirit of the Latin originals while putting the service in the German idiom. He built his German Mass on the principles he had annunciated when he translated the Bible. He wanted it to be thoroughly German in every sense of the word. Luther, however, eliminated the Latin altogether and produced hymns that captured the spirit of the Latin service. The structure of this service: Hymn or psalm - Kyrie - Collect - Epistle - Hymn - Gospel - Nicene Creed ("We All Believe in One True God") - Sermon - Paraphrase of the Our Father - Admonition to the communicants - Christ's Words over the bread and elevation - Distribution of the host (German Sanctus ("Isaiah, Mighty Seer" ("Jesaia, dem Propheten") or some other hymn) - Christ's Words over the cup and elevation - Distribution of the cup (Agnus Dei and German hymns during distribution; no formula is provided) - Post-Communion collect - Aaronic Benediction (LW 53, 1965, p. 51 ff.).

The German service was meant to stand side by side with the Latin Mass and not to replace it entirely. It was meant for the uneducated, and therefore a catechetical spirit predominated throughout. Clearly, it was Luther's inten- 
tion that the people should participate fully, and they are enabled to do so by the German hymns provided, including the sung Nicene Creed and the Sanctus in a German version. Problematic is the replacement of the Preface with the Paraphrase of the Our Father, but here too the emphasis is on the preparation for Communion and the act of Communion.

Although it was not without influence, Deutsche Messe did not have the same impact on Lutheran Mass in the city of Wittenberg in Ernestine Saxony, as did the Formula missae. Mass in Wittenberg in the early 1530's was described in the 1533 Wittenberg church order which was issued by the official visitors of the parishes. This order was influenced by Johannes Bugenhagen, "Doctor Pomeranus". As pastor of the city church, it was within his authority to regulate the conduct of public worship. Wittenberg church order set down the form for the worship and preaching throughout the year. Mass followed a familiar pattern: Benedictus Dominus Deus Israel (Luke 1: 68-79) with antiphon - Introit (Latin or a German psalm) - threefold Kyrie (ninefold on high feasts) - Gloria in excelsis (on high feasts only) - German collect - Epistle - Alleluia, gradual, and German hymn (sequences on high feasts and their seasons) - Gospel - Nicene Creed ("We All Believe in One True God") Sermon - German prayer or hymn. The proper Mass continued with a hymn during the preparation of the bread and wine and the gathering of the communicants - Eucharistic preface and Vere dignum - Our Father - Verba and elevation - Communion (Sanctus and Agnus Dei in Latin as well as German hymns) - Post-Communion collect - Aaronic Benediction. A fundamental difference between the Formula missae and Wittenberg 1533 church order is that Luther's order was descriptive and the 1533 order was prescriptive and had binding force in the Wittenberg congregation and all the parishes in the vicinity of it. Luther annunciated general principles and set them down in general terms, but the Wittenberg 1533 order contained directives that were quite specific (Sehling, 1902, p. 703-705).

Wittenberg and the region surrounding it were in Ernestine Saxony. The Reformation did not come to Albertine Saxony until 1539 when Duke Georg was succeeded by his brother Heinrich. The results of the 1539 visitation showed that a church order to govern all aspects of church life was needed. 
The new church order, completed in autumn 1539, was prepared by Justus Jonas and his colleagues on the basis of earlier documents, including the 1533 Wittenberg order. Justus Jonas, who was Luther's secretary, followed his suggestions closely, offering two Masses: one for city parishes and parishes with schools and the other for village parishes and those without schools. Sunday Mass in city churches: Introit (in Latin) - Kyrie - Gloria in excelsis (in Latin) - Collect (in German or Latin) - Epistle (in German) - Sequence or German psalm, or hymn - Gospel - Nicene Creed (in Latin or "We All Believe in One True God") - Sermon (on the Gospel) - Paraphrasis and Communion exhortation but, especially on high feasts, the Latin preface (the prefaces for major feasts, including Ascension and Trinity Sunday; the Trinity preface may be used also for other Sundays) - Verba - Sanctus (in Latin) Communion (Latin Agnus Dei or German hymns and Psalm 111) - PostCommunion collect - Benediction. The Mass on Sunday in villages without schools: Psalm or suitable hymn - German collect - Epistle - German psalm or hymn - Gospel - Creed ("We All Believe in One True God") - Sermon Paraphrase and admonition - Verba - Communion (German hymns or the German Sanctus, "Isaiah, Mighty Seer") - Post-Communion collect - Benediction. Important in the village congregations were the Communion and the catechesis. The service was simplified so that minds might not wander. None of the Wittenberg reformers appeared to have held out much prospect for the development of any liturgical sophistication among the village dwellers (Kirchen ordnung, 1539, p. D-E).

It is this Albertine church order that would prove to be the most influential in all Saxon territories in future years. It was reprinted many times and left its distinctive mark on Ernestine church orders as well. The most important of these was the 1626 church order of Saxe-Coburg which in turn formed the basis for the later rites as the Ernestine territories came to be divided and subdivided.

The 1539 Albertine church order of Duke Heinrich was printed again in 1540 under the title: Agenda, that is the Church Order... (Agenda Das ist Kirchenordnung...). "Agenda" would from this time come to be the most characteristic term used to describe Lutheran liturgies. In some other territories, the 
order of worship, prayers, and other propers was not published separately but was included in the larger Church Order. Such was the case in Prussia 1568, Courland 1570, Saxe-Coburg 1626, et al. In such cases, this larger book was used by the liturgist in the conduct of liturgical services. In Denmark, the agenda was called the "Altar Book" and in Sweden, the "Handbook." The Scandinavian churches printed these books separately from their church orders which included the ecclesiastical and liturgical directives but did not have in them the divine service itself.

\section{Classification of the Lutheran Liturgies}

The Lutheran Church never adopted one agenda or form of worship to be used everywhere by all, such as one finds in the Roman Catholic Church and the Book of Common Prayer in the Church of England. Luther made no attempt to legislate on liturgical matters, and there was never in any period a single ecclesiastic authority or synod to authorize binding canons, nor was there a single ruling power to either formulate or enforce such.

The first generations of Lutheran reformers declared that human customs, rites, or ceremonies need not be everywhere alike. The Lutherans understood themselves to be heirs of the medieval tradition and used it freely according to the needs of the congregations. The territorial churches bound themselves to the sacred Scriptures, the Ecumenical Creeds, and the Lutheran Confessions, and none of these bound the churches to particular ceremonial expressions. Such were regarded as adiaphora, to be used or not as the situation warranted. However, it was understood that God's gifts given through preaching and sacraments are not adiaphora; the particular ceremonies associated with these rites were understood by Lutherans to be means by which preaching and the sacraments are to be held in reverence and extolled. Free cities and territorial churches were free to make use of the tradition, and even add to it according to the needs of time and place. Thus, there were many agendas, not just one. In the first generation of the Reformation up to the Peace of Augsburg in 1555, at least 135 printed or manuscript church orders were prepared in Germany and Scandinavia. Some liturgies were strictly of local interest 
and soon would be replaced, while others have proved to be of continuing significance (Reed, 1947, p. 89).

Of primary importance are the liturgies of Johannes Bugenhagen whose rites stand in the tradition established by the Formula missae. In addition to the orders he prepared for the Wittenberg congregation itself, he wrote orders for the churches to which he was called to establish the Reformation: Braunschweig 1528, Hamburg 1529, Lübeck 1531, Pomerania 1535/42, Schleswig Holstein 1542, Hildesheim 1542, and 1543. He also left his mark on the Danish Mass found of the Ordinatio ecclesiastica 1537 and 1539/1542 (Niebergall, 1993, p. 15).

Prominent also was the church order of Brandenburg-Nürnberg 1533, prepared by Andreas Osiander and Johannes Brenz. Like the Bugenhagen orders and the 1540 Saxon agenda of Duke Heinrich, the Brandenburg-Nürnberg left a profound influence on other Lutheran Church orders, most especially those of Brandenburg 1540, Brandenburg-Lüneburg 1542, Mecklenburg 1540 and 1552, Cassel 1539, and Köln 1543 (Reed, 1947, p. 96). The order of the Brandenburg-Nürnberg divine service is as follows: Introit or hymn (Latin and German) - Kyrie - Gloria in excelsis (Latin or German) Salutation and collect - Epistle (lectio continua) - Hymn - Gospel (lectio continua) - Nicene Creed (Latin or German) - Sermon - Admonition (not Paraphrasis) - Verba - Sanctus (Latin or German) - Our Father - Pax Domini (in Latin or German) - Communion (Agnus Dei, Communion verse, and other hymns) - Collect - Benedicamus - Benediction (Kirchen Ordnung, 1533, p. 44-51).

Of special interest is the 1540 order approved by Elector Joachim II of Mark-Brandenburg. Much in this order is built on provisions from Brandenburg-Nürnberg 1533 and the Saxon agenda of Duke Heinrich, but this liturgy supplements these provisions with rich ceremonies. As elsewhere, the liturgist and assistants are directed to wear the customary vestments, and they are to approach the altar in a procession led by torchbearers. Before the Mass, the liturgist standing before the altar says the Confiteor in Latin. The Mass follows this order: Introit - Kyrie - Gloria in excelsis - Salutation and collect (all in Latin) - Epistle (sung in Latin and read in German) - Hymn (in Ger- 
man) - Gradual and alleluia or tract, or sequence (in Latin) - Gospel (Latin and German) - Nicene Creed (in Latin but in villages, "We All Believe in One True God") - Offertory verse - Preface and Sanctus (in Latin) - Five collects from the Brandenburg-Nürnberg order for emperor and rulers, the clergy, the unity of the church, and for the forgiveness of sins (in German) Verba (in German) - Elevation - Latin hymn in the cities but in villages, a German hymn - the Our Father (in German) - the Pax Domini - Agnus Dei (in Latin) - Pastor's Communion prayers -Distribution (Latin responsory and German hymns) - Post-Communion collects (in German and Latin). The infirm may be communed after the service in the church or the sacrament may be taken to them in their homes. In the later case, it is accompanied by acolytes with bells and torches (Kirchen Ordnung, 1540, p. Jij-L).

An unusual departure from the usual pattern is found in the Württemberg order of 1553 in which little remains of the Mass, making the divine service almost indistinguishable from that of the Reformed (Calvinist) congregations. The Lutheran congregations of that region normally administered the Sacrament of the Altar twice a month. Where that was not possible, it was administered at least once every month. The pattern was as follows: hymn Sermon - Creed - Admonition to communicants (from 1555 with public confession and absolution) - Prayer of the church - Our Father - Verba - Distribution (hymns during distribution) - Collect of thanksgiving.

An important Scandinavian example is found in the 1531 rite of Olavus Petri. This rite was strongly influenced by Luther's Formula missae and Döber's 1525 German Mass. Uniquely, the Mass begins with a confessional address and includes a general confession of sins, a prayer for forgiveness, and a declaration of grace, probably in imitation of the traditional preparatory prayers of the priest before Mass. Then follows the Mass: Introit or whole psalm - Kyrie - Gloria in excelsis - Salutation and collect - Epistle - Gradual - Gospel - Apostles' Creed (although the Nicene Creed may be used) - Eucharistic preface - Verba - Sanctus - Our Father - Pax Domini - Agnus DeiExhortation to a congregation - Distribution - Salutation - Post-Communion collect - Salutation - Benedicamus - Aaronic Benediction with Triune invocation (Then Swenska Messan, 1531, p. B-C). Editions of this Mass were 
published in 1537, 1541, 1548, and a final edition appeared in 1557 (Pahl, 1983, p. 113-121). In it, the Latin introits and graduals and additional collects translated from the Latin were included. The Mass originally was used in Sweden and Finland, but later it came to be used also in Estonia and Livonia.

It is not that easy to systematize the vast number of church orders, many of which influenced each other. All of them were built in accordance with the principles that Luther had laid down in his liturgical writings. In them, the Sacrament was of first importance and the liturgy was to serve it.

The liturgies may be divided into types. First are those which followed Luther's liturgical writings most closely. These included those of the Saxon churches and those of church orders edited by Wittenberg theologians. Prominent among them were the church orders of Johannes Bugenhagen, the 1525 Prussian church order, and 1540 Duke Heinrich's agenda. Included in this tradition are also Brandenburg-Nürnberg 1533, Hanover 1536, Naumburg 1537, Halle 1541, Mecklenburg 1552 (Rietschel, 1951, p. 364), as well as Briesmann's Riga order of 1530, the Swedish Mass of 1531, and many others.

To the one side of this central Saxon type are those orders which sought to retain more of the medieval rite, while at the same time rejecting the notion of the sacrifice of the Mass. Included among these Masses are the 1540 order of the Margraviate of Brandenburg, Pfalz-Neuburg 1543, and the Austrian 1571 order of David Chyträus (Rietschel, 1951, p. 364). The Red Book, the Liturgia Svecanae of John III 1576, may be included as an example, although some question whether it did not deviate from the principles of the Lutheran liturgy. In the so-called Red Book, the king included a form of Mass that incorporated many of the features of the medieval rite and yet retained the structure of Eucharistic preface - Verba - Sanctus which Olavus Petri had taken from Luther. John III's book said nothing of a sacrifice for the living and the dead (Litvrgia Svecanae, 1576, p. 42-43). It contained copious notes with numerous quotations from the church fathers. Luther and Melanchthon are never quoted, and for this the king was widely faulted. However, Luther and Melanchthon always claimed that they taught what the church had always taught and what had been clearly articulated by its best teachers. That they were not quoted directly could hardly be taken to mean that their position was 
rejected. After the king's death in 1592, the church took a more decided turn toward the center, and the church returned to the use of the 1557 rite.

A third type includes those rites which moved in the direction of the less liturgical tradition. Among these rites are that of Schwäbisch-Hall 1526, Hesse 1532 and 1539, the church orders of Würtemberg 1536, 1553, and 1559, the Baden order of 1556, and others (Rietschel, 1951, p. 364). A twentiethcentury observer said of these orders that they appeared to closely inspect every single "Amen" to determine whether or not it was too Catholic (Sasse, 2013, p. 75).

Classification of the Lutheran rites may also be undertaken on the basis of a determination of the influence of the Formula missae or the Deutsche Messe on them. Some provisions of the Deutsche Messe became pervasive. Among them was the emphasis on the pedagogical elements of the Mass and the replacement of the Eucharistic preface by the Paraphrasis of the Our Father. In his Deutsche Messe, Luther had stated that he recommended this Mass for use among simple people who would never reach any high level of understanding and needed a simple liturgy to encourage them in their faith and sacramental practice. Those who prepared the church orders understood Luther's principle and classified congregations according to their educational level. The 1540 liturgy of Duke Heinrich called for the use of the Eucharistic preface in city churches and churches with schools and directed that in village congregations where there were no schools, the Paraphrasis should be used instead (Kirchen ordnung, 1539, p. Diij). Other writers simply followed the Deutsche Messe and eliminated the Eucharistic preface altogether. Such was the case in the Ducal Prussian orders of 1544, 1558, and 1568 which dropped the 1525 Preface and replaced it with Paraphrase. This was true even in such notable church orders as Brandenburg-Nürnberg 1533 and Pfalz-Neuburg 1543.

A large number of church orders followed the example of the Formula missae and the Deutsche Messe and put the Sanctus after the Verba. Whether Luther's decision to relocate Sanctus was intended to express a joyful thanksgiving to the proclamation of Christ's Testament and to emphasize the thought of the Real Presence is still debatable (Reed, 1947, p. 89; Spinks, 
1982, p. 35-36). Many church orders followed this practice; notable exceptions include the Bugenhagen orders, the 1539 rite of Duke Heinrich, et al.

Almost all the church orders placed at the center of the consecration the Our Father and the Verba without surrounding them with other prayers. In this, they followed Luther who had eliminated those prayers in the medieval Mass which surrounded the Our Father and Verba and made of the Mass a sacrifice for the living and the dead. Luther rejected the theology articulated by these prayers and stated that they were later additions that did not fit theologically or stylistically. It was the Verba which must be extolled as both proclamation of the Testament of Christ and consecration of the Sacrament. Luther not only singularly stated that these words should be sung, but in the Deutsche Messe he stated that they should be sung in the Gospel tone since they were the purest Gospel. An exception to this pattern was found in PfalzNeuburg 1543. Here, the Preface was gone but prayer was added which was addressed to the Son and in which he was asked to receive the bread and wine, and graciously bless and make of them his body and blood and bless those who would partake of these holy gifts with eternal life (Kirchenordnung / "Der ander theyl", 1543, p. 22). The other exception is the 1576 Liturgia Svecanae where the structure of the Roman prayers of the Canon was retained but their content was altered. Nowhere was the body and blood identified as a sacrifice. An additional prayer before the Preface and the Verba, an epiclesis, asked that by the power of the Holy Spirit, God would bless those who rightly receive the body and blood of Christ (Litvrgia Svecanae, 1576, p. 39).

It has troubled many students of the liturgy that Luther did not attempt to construct a Eucharistic Prayer. However, it is clear that it was not his purpose to do so. The rite which he had received from the medieval Church had in it no Eucharistic Prayer as such, and his purpose was to emphasize the fact that the Sacrament is God's gift. According to his thinking, closest attention must be given at this point in the Mass on God's action rather than that of the church. Consequently, he stripped out the prayers of the Canon, leaving only the Our Father and the Qui pridie with the Verba in it. 


\section{Pietist Criticism of External Worship}

The history of the Lutheran liturgy in later times shows the influence of the spiritual and secular movements of the day. The liturgical traditions in the various territorial churches formulated in the sixteenth century became stabilized and continued to be used for over two centuries and in some places into the nineteenth century. New editions of the agendas were published for the purpose of reproducing and even enriching the liturgical traditions of the older church orders and agendas. For example, the 1771 Leipzig and 1747 Coburg Vollständiges Kirchen-Buch (Complete Church Book) included 900 pages of valuable traditional liturgical material. The so-called orthodox period was a time of theological stability, and liturgies of that time sought to maintain the position of the Confessions. In some places, as in East Prussia and Courland, no liturgical revision whatever was undertaken from the later part of the sixteenth century until well into the eighteenth century when new editions of agendas were prepared in 1741 .

There are no early indications of hostility evident against liturgy and worship traditions among the Pietists. Philipp Jakob Spener, whose Pia desideria (Heartfelt Desire) of 1675 had set the movement in motion, held firmly to the liturgy and the traditional ceremonial practices associated with it. $\mathrm{He}$ was convinced that it was necessary to hold the traditional ceremonies of the church and to maintain a fixed order of worship over against the notion of some who attempted to summarily reject liturgical adiaphora as not only unnecessary but as a hindrance to the true worship of the Christian heart. Spener thought that adiaphora was not of great importance but that it was useful in that it edified the people. In addition, he thought that conformity in liturgical customs should be voluntary rather than compulsory so that non-essential ceremonies would not come to be regarded as essential. In summary, his position and that of the early Pietists was to leave the liturgy alone and follow traditional church practices (Almer, 2016, p. 90; Reichert, 1975, p. 93-112).

More critical in their approach were August Hermann Francke and Johann Anastasius Freylinghausen. Beginning in February of 1699, they did away with the exorcism, which was still in common use throughout the Duchy of Magdeburg, and rejected it along with the use of the Mass vestments as a 
"relict of the papacy." In these matters, Spener stated that he was not in agreement, but he was willing to go along with their actions because there was no public furor. He did, however, warned Francke that he must not act arbitrarily. Francke found it necessary to rescind his statements concerning Mass vestments. He had originally justified his rejection of them by stating that they connoted differences in rank at the Lord's Supper (Almer, 2016, p. 91).

More reproving of the Lutheran ceremonial and customs, however, was Christian Thomasius, professor of jurisprudence at the University of Halle. It was his opinion that what was declared adiaphora could either be left to the individual to decide on the basis of his conscience, or it could be regarded as something superstitious and in need of reformation by the prince if this could be done without causing a public stir. According to Thomasius, any and all external worship of God was adiaphora - a matter of indifference. He himself set down as adiaphora seven practices which he considered to be of little value for proper edification from the Pietist point of view. They included the Gregorian calendar, ecclesiastical music, the Mass vestments, the use of images and their veneration, Latin hymns, exorcism in Baptism, and the practice concerning private confession (Thomasius, 2007, p. 99-109). According to the theses and observations of Thomasius, the territorial rules were able to claim the right of making decisions in religious, and especially adiaphora, matters. In all this, Thomasius went much further than anyone of the Pietists had dared to go before him.

As Pietism developed, the Pietists became more and more indifferent to what they regarded as formalism in church ceremonial as strictly external while their own emphasis was on the newness of heart. The internal worship of the heart was emphasized as more important than elaborate liturgical ceremonial.

\section{Influence of the Enlightenment on the Liturgy}

Far more harmful to the church's liturgical heritage was the Enlightenment. Those who supported the new thought insisted that liturgies must be produced which reflected the modern view of God, man, and the world and should accommodate itself to the speech, song, and spirit of the new age. 
The word, which constantly appeared in discussions concerning the need for a new liturgy, was "improvement" (Germ. Verbesserung). Liturgy must be improved not only in some grammatical sense, as though accommodation to modern verbal expressions would be sufficient. Worship itself would need to be adjusted to agree with modern thought and norms. Another commonly used word that stood next to "improvement" was "edification" (Germ. Erbauung). Pietism also emphasized the importance of edification in personal faith and the Christian way of life but always understood that it was the work of the Holy Spirit. Neology viewed Christian edification from the anthropocentric perspective and stressed the power of human reason. Man must be edified, built up, made more than he was before in terms of his moral being.

The pioneer, who first took it in hand to produce a neological agenda in German-speaking lands, was Georg Joachim Zollikofer, minister at the Reformed church in Leipzig. His Anreden und Gebete (Addresses and Prayers), 1777 and 1795, was eagerly grasped by enlightened clergy of both the Reformed and Lutheran confessions. In the opinion of many, this liturgy spoke directly to the heart of modern man in a most remarkable way. Another pioneering neological liturgy was Versuch einer christlich-evangelischen Liturgie (Attempt at a Christian-Evangelical Liturgy), produced in 1782 by Georg Friedrich Seiler. This liturgy became popular enough to warrant a new edition in 1785, and it soon became the most influential and pervasive new liturgical work of the period. It was superseded in 1787-1804 by Allgemeine Sammlung liturgischer Formulare der evangelischen Kirchen (General Collection of Liturgical Forms of the Evangelical Churches) which appeared in three series with several fascicles.

Soon a number of works appeared in rapid succession. In 1784, Neue Liturgie (New Liturgy) by Johann Gottlob Lorenz Sembeck of Linden was printed. Johann Hinrich Pratje, one of the contributors to the Liturgisches Magazin (Liturgical Magazine), published his Liturgisches Archiv (Liturgical Archive) in 1785 as a contribution towards the goal of providing suitable public worship forms for the enlightened. Wilhelm Friedrich Hufnagel's Liturgische Blätter (Liturgical Leaves) 1790-1802 enjoyed great popularity among the clergy. Hufnagel's twelve volumes of liturgical notes gave eviden- 
ce of his interest in every aspect of Christian worship, and the forms of the Lord's Supper and other services which he authored indicate that his goal was to attempt to make the Lord's Supper and other elements of Christian worship meaningful to a rationalist public. Another influential handbook was the work of Christian Gottfried Junge in Nürnberg, published in 1799 under the title: Versuch einer neuen Liturgie (Attempt at a New Liturgy). Unlike many of his contemporaries, Junge offered only one form for the celebration of the Lord's Supper which he supplied with three admonitions, expressing various levels of accommodation to the spirit of Enlightenment. A second work, Neues Agend-Buch (New Agenda Book), appeared in 1801. It was approved by the city council and made official in Nürnberg and its vicinity.

Prussia, which during the reign of Friedrich the Great has often been described as a "metropolis of the Enlightenment" or the "land of freedom of conscience" (Macmillan, 1917, p. 159), proved to be a fertile ground for the sprouting of neological liturgies. In Brandenburg, Christian Wilhelm Krause's Versuch einer Agende (Attempt at an Agenda) appeared in 1788. Krause proposed that his work was meant to rise above confessional differences, but in the spirit of Deism and Naturalism, it actually rose also above Christian particularity as well. In 1793, Wilhelm Abraham Teller, Provost of BerlinCölln, published his contributions to the liturgical reform: Sammlung einiger Gebete zum Gebrauch bey öffentlichen Gottesdiensten (Collection of Some Prayers to Be Used in Public Divine Services). His form for the Lord's Supper came to be used widely and was included in a number of neological agendas. In Pomerania, Anreden und Gebete zum Gebrauch bey dem öffentlichen Gottesdienst (Addresses and Prayers for Use in Public Divine Service), was prepared in 1795 by Superintendent Ehrenfried Christian Colberg and approved by the city council for official use. Superintendent Gottlieb Schlegel of Greifswald published his Kleines liturgisches Handbuch (Little Liturgical Handbook) in 1796. In 1800, he printed yet another collection of formularies and prayers, and a new edition appeared in 1804. Progressive philosophies also gained a foothold in Silesia. In the Duchy of Oels, Agenda, oder: Ordnung der evangelischen Kirchen (Agenda or the Order of the Evangelical Churches) was published in 1804 by Superintendent Elias Gottlieb Dominici. 
He did not cast aside the old, familiar forms but put them always in the first place, at the head of a list of neological alternatives. In the Duchy of Schweidnitz, Pastor Johann Friedrich Wollgast produced in 1810-11 his three-volume liturgical work under the title: Versuch einer möglichst vollständigen Kirchenagende (Attempt at a Possible Complete Church Agenda). He sought to provide city and rural pastors with material to cover every conceivable pastoral situation, but to some, his work was not really sufficiently up-to-date and that it retained too much material which modern thinkers had adjudged insignificant. The rationalistic work of Heinrich Wilhelm Frosch, pastor in the Duchy of Ratibor, appeared in 1802 in his Allgemeine Liturgie oder Versuch (Common Liturgy or Attempt). He published additional volumes in 1805 and 1809. The formularies for the Lord's Supper reveal how thoroughly acquainted he had made himself concerning progressive humanistic interpretations of the Lord's Supper. In Danzig, West Prussia, neological Gebete und Formulare für die öffentliche Gottesverehrung (Prayers and Formularies for the Public Divine Worship) appeared in 1811. The Danzig book demonstrated the spirit of the age by providing a variety of forms that would appeal to man's enlightened spirit. The use of neological liturgies, however, was especially strong in the Prussian Province of Saxony. Most of these liturgies, however, were imports from other territories and had only quasi-official status.

By the 1780s, neology had spread along the northern coasts in the Baltic and could now be found in Courland and Livonia. In 1785, 1786, and 1792 Courlandian Pastor Carl Dietrich Wehrt produced a rationalist agenda: Handlungen und Gebete beym öffentlichen Gottesdienst (Ministrations and Prayers for the Public Divine Service). Wehrt noted that his liturgy was meant to fulfill the wishes of so many enlightened people who have desired the publication of a new culturally relevant agenda to replace the outdated Courlandian handbook. A Livonian liturgical contribution to this collection of formularies was the work of Karl Gottlob Sonntag, General Superintendent of the Livonian Church. His Formulare, Reden und Ansichten (Formularies, Discourses, and Insights) appeared in Riga in 1802 and 1807, and a newly arranged edition was published in Riga in 1818. His works were fully in tune with the spirit of the age and fully embraced rationalist theology. 
Neological liturgies proliferated throughout German-speaking lands, however, many of them were unofficial. Among the agendas that had official status in the entire territory was Ordnung Gebete und Handlungen (Order of Prayers and Ministrations) by Carl Benjamin List, published in Heidelberg in 1783. This work may be described as a moderate neological agenda, for it demonstrated a form of Lutheran liturgy which had by this time come under the influence of the Enlightenment spirit and had adopted some of its thought patterns and terminology. Another neological agenda, Ordnung der Handlungen und Gebete (Order of Ministrations and Prayers), was approved by the Lutheran consistory in Vienna for use in the Lutheran congregations in Austria and published in 1788. In 1797, a rather conservative agenda, Vollständige Pfalzsulzbachische Liturgie (Complete Liturgy of PalatinateSulzbach), appeared for use by the clergy in Palatinate-Sulzbach. The book was prepared by Superintendent Johann Stephan Tretzel and his colleagues at the behest of the territorial government in 1787. Yet another influential agenda which would have official standing was the 1795 and 1801 book, Sammlung von Gebeten und Formularen für gottesdienstliche Handlungen (Collection of Prayers and Formularies for the Divine Worship Ministrations), produced at the request of the Oldenburg consistory by Esdras Heinrich Mutzenbecher, General Superintendent in the Duchy of Oldenburg. In 1797, 1817, and 1824, Schleswig-Holsteinische Kirchen-Agende (SchleswigHolstein Church Agenda), a work deeply influenced by the rationalistic spirit of the age appeared in print in German and Danish editions for use by the church in Schleswig-Holstein. Its author was General Superintendent Jacob Georg Christian Adler. King Christian VII of Denmark gave the handbook his royal approval (Schleswig-Holsteinische Kirchen-Agende, 1797, p. 3-4). The official response to the proliferation of neological rites in Electoral Saxony came in 1812 with the publication in the two-volume official territorial agenda: Kirchenbuch für den evangelischen Gottesdienst der Königlich Sächsischen Lande (Church Book for Evangelical Divine Service in the Territory of the Kingdom of Saxony). Another official agenda was published in 1818 and 1821 for the domain of Arnstadt. Kirchen-Agende für die Herrschaft Arnstadt (Church Agenda for the Lordship of Arnstadt) was the 
work of Gabriel Christoph Benjamin Busch, superintendent of the Lutheran Church in Schwarzburg. The official Lutheran liturgical handbook of that period in the Russian Empire appeared in 1805, in St. Petersburg, under the title: Von Sr. Kaiserlichen Majestät allerhöchst bestätigte Allgemeine Liturgische Verordnung (His Imperial Majesty's General Liturgical Regulation). It was published with the authorization of Tsar Alexander I who decreed that it was to be used without exception in all Lutheran congregations in the empire. The book can be described as the high watermark of ecclesiastical rationalism in Russia proper and the Baltic provinces. A modernized Swedish agenda, Kyrko-handbok, hwaruti stadgas, huru gudstjensten i swenska församlingar skall behandlas (Church Handbook, Ordering How the Divine Service in Swedish Congregations Is to Be Held), was printed in 1811. Although compared to earlier Swedish rites the work was in many ways altered, it assumed a celebration of the Sacrament every Sunday and gave the order of the High Mass ("Högmesso-Gudstjensten") straight through.

Numerous other neological Lutheran agendas appeared in the era of Enlightenment. Most of these works were predominantly anthropocentric and had in them a little trace of sacramental realism. The Lord's Supper was understood to be a solemn remembrance of the death of Jesus the Teacher which he himself had established to remind his followers what he had accomplished for their eternal welfare. It was a symbolical action that reminded the people of Jesus himself in order to strengthen them in their faith and actions to live a proper moral life and reach at length the heavenly goal. The heavenly feast had been turned into an earthly Supper with the heart of the gospel replaced by a serious call to a devout and upright life.

\section{Prussian Union and the Awakening of a New Liturgical Sensibility}

Two factors led to an awakening of interest in the Lutheran liturgy in the early decades of the nineteenth century. Of first importance was the publication of the Prussian agenda by King Friedrich Wilhelm III. The second was the negative reaction against the Prussian Union which showed itself in the awakening of a new appreciation of the Lutheran Confessions. 
By the end of the Napoleonic Wars, more than half of the territories of the emerging German Empire had been incorporated into the Kingdom of Prussia. Many new regions, including Westphalia, Rhineland, Swedish Pomerania, and portions of the Electorate of Saxony, were now under Prussian rule. From a confessional point of view, Prussia was a stronghold for Lutheranism and Roman Catholicism. In 1815, 56 \% of the people were Lutheran, 38 \% were Roman Catholic, and $4 \%$ - Reformed (Die Geschichte, 1992, p. 82). Despite the fact, that Lutherans constituted $93.3 \%$ of all the Prussian Protestants and the Reformed constituted only $6.7 \%$, the king, who himself was a member of the Reformed Church, was concerned to draw Lutheran and Reformed churches in his realm into the ecclesiastical union in which his evangelical subjects were to worship alike regardless of the confession to which they belonged.

In 1814 the king initiated state-sponsored liturgical reform binding on the church, and a year later, he decided to involve himself in the creation of a new liturgy. Subsequently, in 1816, he prepared the liturgical service for Garrison churches in Potsdam and Berlin to be used by all members of the military whether Lutheran or Reformed. By 1821, the booklet had grown into an entire Union agenda, published in separate volumes for both the Royal Army and Berlin Cathedral. The second and third editions appeared in 1822 and 1824 under the same title: Kirchen-Agende für die Hof- und Domkirche in Berlin (Church Agenda for the Court and Cathedral Church in Berlin).

The new service contained within it Lutheran elements which dated back to the time of the Reformation. The divine service included: Hymn - Triune invocation - Adjutorium nostrum - Confession of sins - Verse after confiteor - Kyrie - Gloria in excelsis - Salutation and collect - Epistle - Alleluia Gospel and response "Praise to you, O Christ" - Apostles' Creed - Verse after the creed - "Eucharistic preface" - Tersanctus, Hosanna, and Benedictus qui venit - Prayer of the church - Our Father - Hymn - Sermon - Aaronic Benediction - Concluding hymn verse. If Communion was to be celebrated, the service would continue with: Admonition to Communicants - Prayer Verba - Pax Domini - Agnus Dei - Distribution (referential formula) - Post- 
Communion prayer - Aaronic Benediction - Hymn (Kirchen-Agende, 1822 [1824], p. 9-24).

Initially, the introduction of the agenda was supposed to be voluntary with no coercion, but in 1824 the king made clear that he would be displeased were any to refuse submission. As could be expected, the inevitable result was the sort of murmuring and complaining which developed into what German historians have called "Der Agendenstreit" - the "Agenda Controversy."

Both in Prussia and beyond its borders newspaper and journal articles appeared critically evaluating the agenda. A large number of these articles dealt with its contents. Many complained that the liturgy was completely in the hands of the pastor and the choir. It was something that the clergy did and in which the people were mute spectators. Others regarded this liturgy as an attempt to impose a sort of Roman Catholicism on Protestants. No local variants were permitted; in every province and region the same service was to be used word-forword, and this offended many as unevangelical. It had always been the tradition in Lutheranism that every territory had its own characteristic liturgy, and the Prussian territorial churches had no desire to see these services suppressed in favor of a uniform rite. The inclusion of a referential distribution formula was highly offensive to many Lutherans, and the notion that the Eucharistic Preface and Sanctus should be moved to the Service of the Word was mind-boggling. Some complained about the reintroduction of exorcism in Baptism. Others stated that the selection of prayers was too small. Still, others complained about the time constraints, according to which the service should not last more than one hour. In short, worship ought to be an expression of concord, but now it had become an engine of discord and discontent.

More sharply critical articles appeared which concerned themselves with the relationship between the new liturgy and the doctrinal positions of the churches. The king had thought that he could successfully create for the Reformed and Lutheran Churches one liturgy which would not do violence to the theological position of either church. In his view, doctrine and liturgy were not intimately connected and could be successfully separated by providing a work that each of these two groups could look at and undertake from its own perspective. He thought that he would achieve this purpose by 
repristination of the liturgical traditions of the Reformation, but he either did not realize or refused to admit that even in the earliest days the reformers held contrary doctrinal positions, and these contrary positions were reflected in their liturgies. It was not possible to mix together the realistic sacramental theology of the Lutheran Church with the strictly spiritual understanding of the sacraments by the Reformed. The liturgy might sound somewhat Lutheran but the similarities were really only superficial. The Lutherans would eventually state that the use of the new liturgy violated their confession, and they were constrained by conscience not to use it. The king, however, did not recognize this fundamental difference.

In addition, the reformers viewed the liturgical traditions of the early and medieval periods very differently. The Lutherans largely retained the structure and content of the medieval Mass, while the Reformed very specifically rejected that tradition and sought to construct what they thought to be services of worship that were biblically pure. The Reformed were in no position to criticize the liturgy as inimical to their theology, but they did object that the new liturgy was inimical to their biblicist liturgical tradition and introduced many elements reminiscent of "Roman bondage." Despite the fact that they found the theology of the agenda innocuous, it was to them a Lutheran liturgy and therefore far too Catholic. Critics could also point out that the new liturgy worked at cross-purposes with the whole notion of a Union Church since it exalted the liturgical tradition of one confession at the expense of the other. It would be better not to join the Union, they declared, than to be forced to use the new agenda.

The most difficult and controversial issues, however, concerned legal questions. It had always been generally agreed that the sovereign had not only the right but also the responsibility to safeguard the church's liturgy from arbitrary alterations, additions, and omissions. This right and responsibility were usually referred to as the king's jus liturgicum negativum, and most writers were willing to acknowledge its continued validity. However, it was evident to many that the king had moved far beyond the proper exercise of his office as the liturgy's protector, for now he had produced a new liturgy, and in unmistakably strong terms he was urging the churches to adopt it. This 
represented a jus liturgicum positivum that had never been acknowledged in the past. To many, it represented an unwholesome royal interference into the internal affairs of the church.

Prussian territorial consistories, however, were expected to endorse the king's suggested rite and see to it that their clergy and congregations fell into line. After some strong initial objections by pastors and parishes, by the year $1825,5,343$ out of 7,782 congregations in the Prussian provinces were using the new rite (Handbuch, 1846, p. 299). In order to secure its universal acceptance, the king decided in 1827 to allow each of the provincial consistories to make whatever minor modifications they deemed appropriate (Foerster, 1907, p. 163-164). As a result in 1829-1834, separate editions of the Union agenda with rather minor differences between them were prepared and published for the Prussian provinces. The 1829 Brandenburg agenda was given the title: Agende für die evangelische Kirche in den Königlich Preußischen Landen. Mit besonderen Bestimmungen und Zusätzen für die Provinz Brandenburg (Agenda for the Evangelical Church in the Royal Prussian Lands. With Special Provisions and Additions for the Province of Brandenburg).

In 1830, the Lutheran and Reformed churches of Prussia were set to celebrate the tercentenary of the presentation of the Augsburg Confession. The king decided that to mark the occasion all Prussian congregations of both confessions should celebrate the Lord's Supper according to the new agenda. In addition, henceforth the designations "Lutheran" and "Reformed" were no longer to be used. Prussian Christians of both confessions would now be identified as "Evangelicals" ("Evangelisch") and united in the ecclesiastical administration of a single "Evangelical Church" ("Evangelische Kirche"). In 1834 , the king proclaimed that no other agenda was to be used in his kingdom (Handbuch, 1846, p. 300-307), and the consistories made it amply clear that pastors who refused to conform would be defrocked. If they continued to serve illegally, they would be arrested and tried as criminals.

These actions served as needed encouragement to many to conform, but they also provoked some to react negatively to both the Prussian Union and its agenda. Pastors began again to study the Lutheran Confessions and the church's genuine liturgical heritage. They gained a new appreciation of the 
church's liturgical tradition. The first reaction came in the province of Silesia in 1830 and spread from there to other regions of Prussia. When the king died in 1840, confessional Lutheran pastors and congregations received permission to establish an independent Lutheran Church. However, the title "Lutheran Church" was not be permitted. The confessional group would be called the Old Lutheran Church (Alt-Lutherische Kirche). Elsewhere in Prussia, Lutherans who wished to remain faithful to their church established confessional Lutheran associations or began to make plans to emigrate to North America and later to Oceania.

The Prussian agenda with its union scheme and the resulting controversy moved many to a new appreciation of the confessional Lutheran theology and liturgical heritage. Theologians and pastors, such as Wilhelm Löhe, Theodor Kliefoth, and others, began to study in-depth the history of the Lutheran liturgical tradition as exemplified in the church orders and agendas of the sixteenth century and later. This gave impetuous to the preparation by the territorial churches outside the Prussian Union of agendas which made good use of the fruits of these labors.

New agendas were published in the course of time. Conferences were held in Dresden in 1852, 1854, and 1856 with representatives of the Lutheran churches of the Kingdom of Saxony, Bavaria, Hanover, Würtemberg, Mecklenburg-Schwerin, and Mecklenburg-Strelitz, who examined the various liturgical formularies of these churches and in 1856 published their fundamental theses concerning the divine service. New agendas appeared in Mecklenburg-Schwerin 1867, Reuss-Greiz 1869, Kingdom of Bavaria 1879, Kingdom of Saxony 1880, Lippe-Detmold 1883, Saxe-Weimar 1885, Kassel 1897, Hamburg 1890, and Braunschweig 1895. In 1886, the Old Lutheran Church in Prussia published its agenda. Outside Germany, new agendas appeared in Poland 1886 and 1889, Russian Empire 1832 and 1897, Denmark 1885, Norway 1889, Finland 1886 (published in 1888), and elsewhere. In 1895, a revised edition of the Prussian Union agenda itself was published and distributed (Rietschel, 1951, p. 390-395). 


\section{Heightened Liturgical Awareness in the Twentieth Century}

The nineteenth century saw an increasing interest in the scholarly study of Christian liturgy, worship, and traditions. In Lutheranism, this study was left largely in the hands of individual scholars and committees charged with the liturgical study. No centralized liturgical movement emerged from this as had been the case in the Roman Catholic Church.

This situation changed in the twentieth century when the study of the liturgical tradition and worship emerged as major scholarly subjects. In Germany, scholars and pastors formed liturgical movements which brought into consideration both confessional particularity and a modern ecumenical spirit. Among the principal purposes of these movements was the development of a new appreciation of the church's liturgical treasures and the relationship between public worship and the life of the congregation. These movements sought to bind the people more closely to the living proclamation of the word of God and the sacramental life of the church. They had no authority to issue official liturgies, but they did publish and circulate private agendas to be used by those who shared their concerns and vision. Here may be mentioned the important role played by such scholars as Rudolph Otto, who gave particular emphasis to the importance of the numinous and holy silence, and Friedrich Heiler who coined the phrase "Evangelical Catholicism" and whose Evangelical Ecumenical Union of the Augsburg Confession (EvangelischÖkumenische Vereinigung des Augsburgischen Bekenntnisses) brought into association pastors and members concerned about the catholic continuity of the Lutheran Church. The Berneuchen Movement (Berneuchener Bewegung), founded in 1923, and its daughter organization, the Brotherhood of St. Michael (Michaelsbruderschaft), brought together in 1931 under the leadership of Wilhelm Stählin and Karl Bernhard Ritter those who were concerned about the relationship of the church to the general culture in which it found itself. This movement was responsible for the publication of a large number of books on the order of Mass, daily offices, and worship life in general. A daily office book was also produced by the Alpirsbach group (Kirchliche Arbeit Alpirsbach), organized in 1933 under the leadership of Richard Gölz and Friedrich Buchholz. It was strongly influenced both by the theology of 
Karl Barth and the pre-Reformation Gregorian chant. Scholars particularly addressed the pressing theological, ecclesiastical, and social problems of the time, devoted themselves to the study of Luther, tried to reform worship services based on the knowledge gained in the course of recent historical and liturgical research.

In the Swedish Church, which retained more ties to medieval tradition than other Nordic or German Lutheran Churches, a new appreciation of the theological dimensions of worship and of their implications for its renewal came through the High Church Movement. In 1920, on the initiative of Archbishop Nathan Söderblom, Societas Sanctce Birgittce was founded, bringing together theologians, clergy, and laity who sought a more ceremonial celebration of Mass and scriptural preaching. High church Lutheranism spread rapidly into parishes through the efforts of Gunnar Rosendal, Olov Hartman, and Jan Redin and prompted the emergence of retreat centers, more frequent celebrations of Mass, and a return to fuller use of ceremonial. The more subtle high church influence, which centered on piety of the Christian life in relation to the sacraments and which combined pietist pastoral care with high church Lutheran ecclesiology, was promoted by Bishop Bo Giertz.

Liturgical interest began in American Lutheranism in the opening years of the twentieth century with the organization of the Lutheran Liturgical Association in 1898 and its publication of Liturgical Memoirs between 1898 and 1906. The Liturgical Society of Saint James, which had been in existence from 1929 until 1947, took an interest in parish renewal through more liturgical services and published its periodical, Pro Ecclesia Lutherana. An important contribution to the study and renewal of the liturgy was made by liturgiologists Berthold von Schenk, Fred Lindemann, Adolf Wismar, Arthur Carl Piepkorn, and others. Strongly influential were the Institute of Liturgical Studies of the University of Valparaiso, founded in 1949, and from 1977-78, the annual Liturgical Symposium of Concordia Theological Seminary, Fort Wayne. A number of associations of scholars and pastors interested in the liturgy and its central place in the life of the church, such as the Lutheran Liturgical Prayer Brotherhood in the Lutheran Church Missouri Synod and groups now associated with the Evangelical Lutheran Church in America, were active. Influential publications 
have included an ecumenical journal Una Sancta, edited for many years by Richard John Neuhaus, periodicals The Bride of Christ and Gottesdienst, evangelical catholic journals - Lutheran Forum and Pro Ecclesia, which put special emphasis on the catholic heritage of Lutheranism. Both the American Lutheran Publicity Bureau and Concordia Publishing House have issued liturgical daily prayer books and other relevant materials promoting liturgical life in congregations and among pastors and laity.

Liturgical studies have strongly influenced the agendas approved for use in Lutheran Churches in Germany and North America. In 1948, most of the Lutheran Churches in Germany joined together to form the United Evangelical Lutheran Church of Germany (Vereinigte Evangelisch-Lutherische Kirche Deutschlands VELKD). In 1954, the Agende für die Vereinigte Evangelisch-Lutherische Kirche Deutschlands (Agenda for the United Evangelical Lutheran Church of Germa$n y$ ), was approved - the fruit of the work of the Lutheran Liturgical Conference (Lutherische Liturgische Konferenz) which since 1941 had been led by Christian Mahrenholz. The official publication of the first volume, Der Hauptgottesdienst (The Chief Divine Service), was published in 1955. Over the course of several years, it was officially adopted by the churches of VELKD.

In 1953, the Evangelical Church of the Old Prussian Union reconstituted itself as the Evangelical Church of the Union (Evangelische Kirche der Union - EKU). At that time, the Prussian agenda of 1895 was still the official standard liturgy in the Union congregations. In 1948, a draft agenda was produced by the Union Church of Westphalia. In 1952, Bishop Otto Dibelius issued another draft agenda for use in the territorial church of Berlin-Brandenburg, more closely based on the 1895 book. After several years of consultations, Agende für die Evangelische Kirche der Union (The Agenda for the Evangelical Church of the Union), was presented to the synod of the EKU and approved in 1959. Volume one was given the title: Die Gemeindegottesdienste (The Congregational Divine Service).

During the last decade of the twentieth century, the work of the German Lutheran Liturgical Conference, together with a working group consisting of representatives of the EKU and the VELKD, bore fruit in the preliminary draft of the Erneuerte Agende of 1990. Further work, the results of which 
were approved by the General Synod and the Bishops Conference of the VELKD in October 1998 and the Synod of the EKU in June 1999, resulted in the publication of a new Evangelisches Gottesdienstbuch (Evangelical Divine Service Book) to serve as the first volume of the agendas of both the EKU and VELKD. Now, for the first time, both churches have a single common worship book for use in congregations of the Lutheran and Union traditions (Evangelisches Gottesdienstbuch, 2000, p. 5).

In the mid-twentieth century, Lutherans in America were using agendas produced by their own synods. The Lutheran Church - Missouri Synod and other churches of the Evangelical Lutheran Synodical Conference of North America used the altar book, The Lutheran Liturgy of 1943 and the book of pastoral acts, The Lutheran Agenda of 1948. The divine service in The Lutheran Liturgy was based on the Common Service for Use of the Evangelical Lutheran Congregations of 1888, which was closely related to the Church Book for the Use of the Evangelical Lutheran Congregations, originally published in 1868 by the General Council. German speaking Lutherans in the Missouri Synod used the synod's Saxon-based Kirchen-Agende für Evangelisch-Lutherische Gemeinden ungeänderter Augsburgischer Confession (Church Agenda for Evangelical Lutheran Congregations of the Unaltered Augsburg Confession) of 1856. German-speaking Lutherans in the General Council used a German version of the Church Book which appeared as the Kirchenbuch für evangelisch-lutherische Gemeinden (Church Book for Evangelical Lutheran Congregations), 1877. The Missouri Synod adopted the Common Service when the English District joined the Synod in 1911 (Pahl, 2005, p. 363-367; Precht, 1984, p. 98-104). New editions of its altar book, Lutheran Worship: Altar Book, and agenda, Lutheran Worship: Agenda, appeared in 1982 and 1984, and in 2006, these volumes were replaced by their new versions: Lutheran Service Book: Agenda and Lutheran Service Book: Altar Book.

Other Lutheran bodies in North America continued to use their traditional agendas either in their native languages, an English translation, or the Common Service. In 1958, they authorized the publication of the Service Book and Hymnal of the Lutheran Church in America which included also pastoral acts (agenda). The Service Book and Hymnal was used until 1978 when the Lutheran Book of Worship appeared. It was the fruit of the labors of the In- 
terlutheran Commission on Worship and included an altar book and a book of pastoral acts. This agenda and hymnal were made the official liturgy of the churches which merged to form the Evangelical Lutheran Church in America in 1988. In 2006, a new worship book, Evangelical Lutheran Worship, for use in the Evangelical Lutheran Church in America and the Evangelical Lutheran Church in Canada was published that replaced its predecessor.

Scandinavian churches also updated their worship books in the course of the twentieth century. The new Swedish handbook which corrected deficiencies of the 1811 agenda was published in 1942. It was, in turn, replaced by a new handbook in 1986 and 2017. A new altar book in Denmark appeared in 1992 which replaced services based on the old 1885 book. The Norwegian 1889 altar book was revised in 1920 and replaced by a new book in 1992 . The Iceland Church published a new altar book in 1981, replacing books published in 1910 and 1934. In Finland, the 1886 liturgy was revised in 1913, 1958-68, 1984, and 1999-2003.

In the course of the twentieth century, most Lutheran Churches revised their liturgies based upon a renewed appreciation of their own liturgical heritage, the scholarly work being done in other Lutheran churches, and ecumenical interests.

\section{Conclusion}

Theological principles of the Lutheran liturgy derive from its confession. In its worship, the church puts into words and actions the faith which it otherwise articulates in its creeds and confessions. The liturgy bears public witness to the faith but it is not faith's source and norm. Although prayer and faith are integral to each other, the church's lex orandi flows out of the lex credendi.

Apology of the Augsburg Confession makes a distinction between the sacramental and sacrificial elements of the service. Sacramental acts are those acts of God by which, through means, he offers and bestows his wholesome grace and blessing. Sacrificial are the acts of worship directed toward God - words and acts of the church in faithful response to the gracious words and acts of God.

The shape of the Lutheran divine service is the traditional Mass of the Western Church. It retains the two-part structure of Missa Catechumenorum 
and Missa Fidelium. The rich use of hymns of praise and prayer, which are confessional in nature, plays an important role in the Lutheran Mass.

The Lutheran Church never adopted one agenda or form of worship to be used everywhere and by all, such as one finds in the Roman Catholic Church. Luther made no attempt to legislate on liturgical matters, and there was never a single ecclesiastic authority or synod to authorize binding canons upon all Lutherans. Thus, there were many agendas, not just one. Historically, their form and use of the Mass, however, in varying degrees derived from Martin Luther's Formula missae of 1523 or Deutsche Messe of 1526.

Lutheran liturgies can be divided into types. The first includes those rites which followed Luther's liturgical writings most closely. The second type comprises those orders which sought to retain more of the medieval rite, and a third type includes those rites which moved towards the less liturgical worship. Classification of the Lutheran rites may also be undertaken on the basis of a determination of the influence of the Formula missae or the Deutsche Messe on them.

Although the Pietists regarded the liturgy as strictly external in comparison to their own emphasis on the newness of the heart, there are no early indications of hostility evident against liturgy and worship traditions among them. Spener thought that liturgy as adiaphora was not of great importance but that it was useful in that it edified the people. More critical of Lutheran ceremonial and customs was the Halle School and particularly Christian Thomasius who set down as adiaphora some practices to be of little value from the Pietist perspective.

Much more harmful to the church's liturgical heritage was the Enlightenment thought. The proponents of the new philosophy insisted that new liturgies must be produced which reflected the modern view of God, man, and the world. Neological agendas proliferated. Most of these works were predominantly anthropocentric and had in them little trace of sacramental realism.

The awakening of a new appreciation of the Lutheran liturgy came in reaction to the Prussian Union and its agenda. King Friedrich Wilhelm III refused to admit that the contrary doctrinal positions of both churches were reflected in their liturgies and that it was not possible to mix together the realistic sacramental theology of the Lutheran Church with the strictly spiritual understanding of the sacraments by the Reformed. The Prussian agenda 
with its union scheme moved many Lutherans to a new appreciation of the confessional Lutheran theology and liturgical heritage. New agendas were published in Germany, Scandinavia, Russian Empire, and elsewhere.

In the first half of the twentieth century, Lutheran theologians and pastors formed liturgical movements which brought into consideration both confessional particularity and a modern ecumenical spirit. Among the principal purposes of these movements was the development of a new appreciation of the church's liturgical treasures and the relationship between public worship and the life of the congregation. They sought to bind the people more closely to the living proclamation of the word of God and the sacramental life of the church.

In the twentieth century, most Lutheran churches revised their rites based on the knowledge gained in the course of recent historical and liturgical research, a new appreciation of their own liturgical heritage as well as from ecumenical interests and influences.

\section{Bibliography}

Almer, G. (2016). Calvinista Aulico-Politicus. Konfession und Herrschaft in Brandenburg-Preußen (ca. 1660-1740). https://refubium.fu-berlin.de/bitstream/ handle/fub188/4392/Almer_Gabriel.diss.pdf.

Artickel der Ceremonien vnd anderen Kirchen Ordnung. (1526). Königsberg: Königsberg: Hans Weinreich.

Bibliotheca Agendorum, Bestehend aus einem Vollständigem Catalogo Derer Kirchen-Ordnungen, Agenden, Und anderer Dergleichen Schrifften... Von Hermann Caspar König, SS. Th. St. Zelle. (1726). Zelle: Hoffmann.

Die Geschichte der Evangelischen Kirche der Union. (1992). Band 1. Die Anfänge der Union unter landesherrlichem Kirchenregiment (1817-1850). Herausgegeben von J. F. Gerhard Goeters und Rudolf Mau. Leipzig: Evangelische Verlagsanstalt. Evangelisches Gottesdienstbuch. Agende für die Evangelische Kirche der Union und für die Vereinigte Evangelisch-Lutherische Kirche Deutschlands. (2000). Berlin: Evang. Haupt-Bibelges und von Cansteinsche Bibelanst.

Foerster, E. (1905). Die Entstehung der preussischen Landeskirche unter der Regierung König Friedrich Wilhelms III.: nach den Quellen erzählt. Ein Beitrag zur Geschichte der Kirchenbildung im deutschen Protestantismus. Erster Band. Tübingen: Mohr.

Foerster, E. (1907). Die Entstehung der Preußischen Landeskirche unter der Regierung König Friedrich Wilhelms des Dritten nach den Quellen erzählt; ein Beitrag 
zur Geschichte der Kirchenbildung im deutschen Protestantismus. Zweiter Band. Tübingen: Mohr.

Graff, P. (1994). Geschichte der Auflösung der alten gottesdienstlichen Formen in der evangelischen Kirche Deutschlands. I. Band. Bis zum Eintritt der Aufklärung und des Rationalismus. Nachdruck der zweiten vermehrten und verbesserten Auflage von 1937. Waltrop: Hartmut Spenner.

Handbuch der kirchlichen gesetzgebung Preussens. Für geistliche, kirchenpatrone, verwaltungsbeamte und juristen. (1846). Herausgegeben von Adolph Heckert. Erster Band. Berlin: Heymann.

Kirchen Ordnug (...) Wie man sich bayde mit der Leer vnd Ceremonien halten sole. (1533). Nürnberg: Gutknecht.

Kirchen ordnung zum anfang für die Pfarher in Hertzog Heinrichs zu Sachsen V. G. H. Fürstenthumb. (1539). Dreßden: Stöckel.

Kirchen-Agende für die Hof-und Domkirche in Berlin. (1822 [1824]). Zweite auflage. Berlin: Dieterici.

Kirchenordnung, Wie es mit der Christlichen Lehre, heiligen Sacramenten, vnd allerley andern Ceremonien, in meines gnedigen herrn, Herrn Otthainrichen. (1543). Nürnberg: Petreius.

Kurtz Ordnung des Kirchendiensts, Sampt eyner Vorrede von Ceremonien (...) zu Riga ghesungen warden. (1530). Rostock: Ludowich Dietz.

Litvrgia Svecanae Ecclesiae Catholicae \& Orthodoxae Conformis. (1576). Stocholmiæ excudebat Torbernus Tidemanni.

LW 35. (1960). Luther's Works 35. Philadelphia: Muhlenberg Press, p. 45-74, 75-112.

LW 36. (1959). Luther's Works 36. Philadelphia: Muhlenberg Press, p. 3-230.

LW 53. (1965). Luther's Works 53. Philadelphia: Muhlenberg Press, p. 7-14, 15-40, 51-90.

Macmillan, K. D. (1917). Protestantism in Germany. Princeton: University Press.

Niebergall, A. (1993). Agende. Theologische Realenzyklopädie. Teil 1, Bd. 2. Berlin: de Gruyter.

Pahl, I. (1983). Coena Domini I. Die Abendmahlsliturgie der Reformationskirchen im 16./17. Jahrhundert. Spicilegium Friburgense. Texte zur Geschichte des kirchlichen Lebens. Vol. 29. Fribourg: Universitätsverlag.

Pahl, I. (2005). Coena Domini II. Die Abendmahlsliturgie der Reformationskirchen vom 18. bis zum frühen 20. Jahrhundert. Spicilegium Friburgense. Texte zur Geschichte des kirchlichen Lebens, Vol. 43. Fribourg: Academic Press.

Piepkorn, A. C. (1956). The Survival of the Historic Vestments in the Lutheran Church after 1555. Saint Louis: Concordia Seminary.

Precht, F. L. (1984). Worship Resources in Missouri Synod's History. Lutheran Worship: History and Practice. St. Louis: Concordia Publishin House. 
Reed, L. D. (1947). The Lutheran Liturgy. Philadelphia: Muhlenberg Press.

Reichert, D. (1975). Der Weg protestantischer Liturgik zwischen Orthodoxie und Aufklärung. Münster.

Rietschel, G. (1951). Lehrbuch der Liturgik. Band I. Die Lehre vom Gemeindegottesdienst. Zweite neubearbeitete Auflage von Paul Graff. Göttingen: Vandenhoeck \& Ruprecht.

Sasse, H. (2013). Letters to Lutheram Pastors, Vol. 1: 1948-1951. Saint Louis: Concordia Publishing House.

Schleswig-Holsteinische Kirchen-Agende. Auf Allerhöchsten Königlichen Befehl zum allgemeinen Gebrauch in den Herzogthümern Schleswig und Holstein, der Herrschaft Pinneberg, der Grafschaft Ranzau und der Stadt Altona verordnet. (1797). Schleswig: Röhß.

Sehling, E. (1902). Die evangelischen Kirchenordnungen des XVI. Jahrhunderts. Erste Abtheilung. Sachsen und Thüringen, nebst angrenzenden Gebieten. Erste Hälfte. Die ordnungen Luthers. Die Ernestinischen und Albertinischen gebiete. Leipzig: Reisland.

Smend, J. (1896). Die evangelischen deutschen Messen bis zu Luthers Deutscher Messe. Göttingen: Vandenhoeck \& Ruprecht.

Spinks, B. (1982). Luther's Liturgical Criteria and His Reform of the Canon of the Mass. Grove Liturgical Study, No. 30. Bramcote: Grove Books.

The Book of Concord. (2000). The Confessions of the Evangelical Lutheran Church. Edited by R. Kolb, T. J. Wengert. Minneapolis: Fortress Press.

Then Swenska Messan epter som hon nw holles $j$ Stocholm medh orsaker hwar före hon så hallen wardher. (1531). Stocholm.

Thomasius, Chr. (2007). Essays on Church, State, and Politics. Edited, Translated, and with an Introduction by I. Hunter, T. Ahnert, F. Grunert. Indianapolis: Liberty Fund Inc. 